\title{
The Effectiveness of Dictogloss in Developing General Writing Skill of Iranian Intermediate EFL learners
}

\author{
Gholam-Reza Abbasian (Corresponding author) \\ Imam Ali and IA (South Tehran Branch) Universities, Iran \\ Mahsa Mohammadi \\ Tehran Azad University(South Tehran Branch), Iran
}

\begin{abstract}
Recent research has shown the need for activities that provide an environment for students to focus their attention on both form and meaning. Dictogloss, introduced by Wajnryb in1990, can be considered as a way for integrating form and meaning in the learning context. This study investigated the effect of dictogloss on Iranian EFL learners' general writing skill. The participants receiving a pre- test and post-test were divided into equal groups in the form of experimental and control group, but only the former received taskbased instruction while the latter was exposed to the mainstream of controversial instruction. Going through rigorous and multiple statistical analyses such as data normality check, instrument validation and running mainly certain parametric statistics, the study revealed two distinctive manifestations: integrative and discrete. Integratively, the treatment affected positively the participants' general writing ability, however, discretely the effects on the organization and mechanics were positive, while content, usage and vocabulary dimensions of their writing were not much affected.
\end{abstract}

Index Terms - dictogloss, writing skill, writing component

\section{INTRODUCTION}

Language teaching and learning have gone through a transient pass. It has reached to the point that more communicative approaches and techniques are used. However, Pica (2000) indicates that neither traditional methods nor more recent, communicative approaches, used alone, have been able to address the scope and level of English proficiency required for participation in today's global community. It seems plausible to integrate both. Moreover, as cited in Nassaji (2000,p.242) "many second language acquisition researchers now argue that exposure to language is not enough (DeKeyser, 1998; Doughty, 1991; Harley, 1998; Harley \& Swain, 1984; Lightbown, 1991, 1998; Lightbown \& Spada, 1990; Robinson, 1996; Spada \& Lightbown, 1993; Swain, 1985)". Advocating a more form-focused approach, these researchers argue that focusing solely on message is not enough so, some sort of form-focused activities in the communicative classroom contexts need to be included. Ellis (2001) believes that recent findings of classroom research also appear to demonstrate that form-focused instruction is beneficial to learners in modifying their interlanguage grammar, thereby leading to improved linguistic accuracy in language use .Moreover he states what is established in recent literature is the characterization of Focus on Form (FonF) as a pedagogical intervention that focuses primarily on meaning while attending to such linguistic elements as grammar, vocabulary and pronunciation via communicative tasks. Shak mentions "FonF is different from Focus on Forms (FonFs) instruction in that its emphasis is mostly on discrete pre-selected form(s), and it typically involves intensive and systematic treatment of those linguistic elements. Moreover, there is usually a lack of correspondence between the forms practiced and their use in 'real' discourse" (2006, p.47).

Nassaji (2000) suggests that using collaborative tasks requiring learners to get involved in deliberate and cooperative comprehension and production of the language, e.g., through the use of dictogloss (DG) can be a way of integrating (FonF) and communication by process. "Dictogloss is defined as a classroom dictation activity where learners listen to a passage, note down key words and then work together to create a reconstructed version of the text. It was originally introduced by Ruth Wajnryb (1990) as an alternative method to teaching grammar" (Vasiljevic, 2010, p.41).

Shak (2006) considers dictogloss as a type of FonF task which proposes to provide a meaning-focused context to raise learners' awareness of the discoursal use of the target linguistic feature. Furthermore, Al-Sibai (2008) regards it as an integration of both traditional and communicative notions. According to Pica (1997), dictogloss is an effective way to integrate traditional concerns for grammar instruction with the communicative technique of pair-work or group-work.

Dictogloss (DG) works its way up in the research context by presenting several advantages. First, its discourseoriented view of language has made DG popular in EFL methodology because it emphasizes on the meaning of a whole text (Mayo, 2002; Thornbury, 1997). Second, DG can provide multiple opportunities to draw L2 learners' attention to target linguistic forms in meaningful contexts (Swain \& Lapkin, 1998). Swain's Output Hypothesis (1985) holds that 
learners' strife to produce comprehensible output would prompt internalization, and thus acquisition of target forms. Qin (2008) considers 'metatalk' or 'Language Related Episodes' (LREs) as the most empirically examined benefit of DG. During dialogues in collaborative tasks (e.g. reconstruction), learners can be prompted to notice linguistic problems and then engage in discussing language forms so that meaning can be made clearer (Al-Sibai, 2008). Therefore, providing meaningful contexts, a chance for L2 learners to both pay attention to and negotiate forms, is another important benefit of DG. Furthermore, Jacobs and Small (2003) believe that "among the reasons given for advocating the use of dictogloss are that students are encouraged to focus some of their attention on form and that all four language skills" (p.2). By and large, DG might be considered as an omnipotent task, shedding light on various aspects. Its effect on writing skill was investigated by Jacob and Small in 2003.

Till now many researchers (Swain \& Lapkin, 1998; Storch, 1998; Nabei, 1996; Lim \& Jacobs, 2001; Shak, 2006; AlSibai, 2008) have worked on dictogloss to discern its effects on language learning especially on listening, vocabulary and grammar skills. Nevertheless, a more fruitful avenue would be to be well-versed in its impact on writing skill. To this end, this study sought to explore the possible improvement of learners' writing achievement through dictogloss activity. More specifically, the study aimed at exploring the effect of dictogloss on learners' writing in general and its areas including content, organization, vocabulary, language usage, and mechanics in particular.

\section{Research Null Hypotheses}

Concretely speaking, the problem and purpose of the study are raised in the form of a major null hypothesis followed by five minor hypotheses, each addressing a separate area of writing skill.

H01: Dictogloss does not have any significant effect on developing EFL learners' general writing ability accommodating five main areas including: writing content, organization, vocabulary, language usage, and mechanics areas.

\section{Methodology}

\section{A. Participants}

The participants of the study were 70 Iranian EFL learners from Tehran Institute of Technology with an age range of 21-48. Based on their position on the normal probability distribution table, 7 of them were discarded as outliers. Moreover, 3 learners were considered as missing participants since they did not answer the questionnaire completely. By and large, 60 learners composed the final sample of this research. Out of 60 participants, 35 of whom were female and 25 were male.

\section{B. Instrumentation}

To conduct this study, a number of instruments including material and tests were used.

Texts

For the purpose of this study the pre-intermediate level of "Let's Talk" by Leo Jones (2007) was chosen, following Read's advice (2006) that the text be comprehensible to the learners.

The length of the text was set based on synthesis of Read's (2009) and Nabei's ideas (1996). The length of the texts was not as short as Read's proposal to avoid both the memorization of the texts but to let learners get the general idea and rely on their creativity in text reconstruction phase. The topics were many argumentative to boost up conversation and let learners talk more for reaching a conclusion. For this particular purpose, eight dictogloss texts were prepared. All the while, parameters such as the topics of each text, their level of difficulty, and their length were taken into account. Moreover, in order to make sure of the consistency of reading speed, texts were read by a tape.

Key English Test (KET)

Before rendering the treatment, the researchers tried to make sure of the homogeneity of groups and since learners were pre-intermediate level, the Key English Test (KET) was utilized for the selection of homogenous sample.

Researcher-made Tests

Furthermore, argumentative composition was set as a post and pretest to diagnose participants' writing ability prior to the treatment and to measure the progress following the treatment.

\section{Procedure}

Initially, the KET was administered to select a homogeneous sample, whereby those who scored only two standard deviation below and above the mean represented the sample of this study. Then, to assess their writing proficiency, the participants were required as a pre-test to write an argumentative composition. On the basis of convenient sampling, they were assigned to two groups; one control group and one experimental group. The former was exposed to conventional teaching, but latter to dictogloss. Although a semester lasts for 11 sessions, only 9 sessions were dedicated to the experiment since the first and the last sessions were for administering the pre- and posttest.

The experimental group received instruction on the steps of dictogloss including preparation, dictation, note-taking, reconstruction. At the beginning of the activity, before reading the text for the first time, the participants were reminded not to write down but only to listen for general meaning. And before the second reading, they were asked to take note what they thought would be important for them to reconstruct the passage. Once the whole class grasped the steps on doing the dictogloss, they were told that this session was only a trial session and that they were required to go through 
the same procedures for the next 8 sessions. Eventually, the posttest was administered during the $6^{\text {th }}$ session to explore the extent to what the treatment benefited participants.

Using analytic scoring method (Heaton, 1988), two raters scored their writing performance both prior to and after the treatment.

\section{RESULTS}

Data analysis went through a sequential steps and procedures including normality check, instrument validation, and testing the hypotheses based on parametric statistics; t-test, ANCOVA and a paired-samples t-test.

Commonly, four assumptions of interval data, independence, normality check and homogeneity of variances should be met before running any parametric statistics (Field, 2009). Measured on an interval scale, the data enjoyed the assumptions of independence since none of the subjects participated in more than one group. The assumption of normality as measured through the ratios of skewness and kurtosis over their respective standard errors (Field, 2009) is displayed in Table 1 in which the ratios of skewness and kurtosis over their standard errors are all within the ranges of plus and minus 1.96 .

TABLE 1.

NORMALITY TESTS

\begin{tabular}{|c|c|c|c|c|c|c|}
\hline & \multicolumn{3}{|c|}{ Skewness } & \multicolumn{3}{|l|}{ Kurtosis } \\
\hline & Statistic & Std. Error & Normality & Statistic & Std. Error & Normality \\
\hline KET & -.236 & .309 & $\underline{-0.76}$ & -1.235 & .608 & $\underline{-2.03}$ \\
\hline PRETESTWR & -.572 & .309 & -1.85 & -.425 & .608 & $\overline{-0.70}$ \\
\hline POSTESTWR & -.264 & .309 & $\underline{-0.85}$ & -.727 & 608 & -1.20 \\
\hline
\end{tabular}

Furthermore, in order to ensure the homogeneity of groups at the very beginning of the term, a Mann-Whitney U test was used. Based on the results displayed in Table 2, it can be concluded that the experimental group $(\mathrm{Mdn}=83)$ did not significantly differ from the control group $(\mathrm{Mdn}=82)$ on the KET, $\mathrm{U}=491, \mathrm{z}=-0459, \mathrm{~ns}, \mathrm{r}=-.059$.

TABLE 2.

MANN-WHITNEY U TEST KET BY GROUP

\begin{tabular}{ll}
\hline & KET \\
\hline Mann-Whitney U & 419.000 \\
Wilcoxon W & 884.000 \\
Z & -.459 \\
Sig. (2-tailed) & .646 \\
$\mathrm{r}$ & -.059 \\
\hline
\end{tabular}

\section{A. Instrument Validation}

To make sure of the validity and reliability of the writing tests, in addition to content validity, reliability coefficient was also estimated. As Table 3 presents, both the inter-rater reliability index for the two raters who rated the writings on pretest and posttest are $.96(\mathrm{P}=.000<.05)$.

TABLE 3.

INTER-RATER RELIABILITY PRETEST AND POSTTEST

\begin{tabular}{llll}
\hline & & Pretest Rater 2 & Posttest Rater 2 \\
\hline \multirow{2}{*}{$\begin{array}{l}\text { Pretest } \\
\text { Rater 1 }\end{array}$} & Pearson Correlation & $.961^{* *}$ & - \\
& Sig. (2-tailed) & .000 & - \\
\multirow{2}{*}{ Posttest } & $\mathrm{N}$ & 60 & $.962^{* *}$ \\
Rater 1 & Pearson Correlation & - & .000 \\
& Sig. (2-tailed) & - & 60 \\
\hline$* *$ Correlation is significant at the 0.01 level (2-tailed). & - & \\
\hline
\end{tabular}

\section{B. Hypotheses Testing}

An independent t-test was run to compare the experimental and control groups' mean scores on pretest of writing in order to prove that the two groups enjoyed the same level of writing ability prior to the main study. As displayed in Table 4, the mean scores for experimental and control groups on pretest of writing are 78.53 and 78.85 , respectively.

TABLE 4.

DESCRIPTIVE STATISTICS PRETEST OF WRITING BY GROUPS

\begin{tabular}{lllll}
\hline Group & $\mathrm{N}$ & Mean & Std. Deviation & Std. Error Mean \\
\hline Control & 30 & 78.8500 & 8.209 & 1.4988 \\
Experimental & 30 & 78.5333 & 9.134 & 1.6678 \\
\hline
\end{tabular}


The results of the independent $\mathrm{t}$-test in Table $5(\mathrm{t}(58)=.14, \mathrm{P}=.88>.05)$ indicate that there is not any significant difference between experimental and control groups' mean scores on the pretest of writing, because the t-observed (.14) is less than the t-critical (i.e. 2.02) at .05 level of significance.

TABLE 5.

INDEPENDENT T-TEST PRETEST OF WRITING BY GROUPS

\begin{tabular}{|c|c|c|c|c|c|c|c|c|}
\hline \multirow[t]{2}{*}{.1} & \multirow{2}{*}{$\begin{array}{l}\text { Levene's Test for } \\
\text { Equality of Variances } \\
\text { F } \quad \text { F Sig. }\end{array}$} & \multicolumn{7}{|c|}{ t-test for Equality of Means } \\
\hline & & $\mathrm{T}$ & df & Sig. (2-tailed) & Mean Difference & $\begin{array}{l}\text { Std. Error } \\
\text { Difference }\end{array}$ & \multicolumn{2}{|c|}{$\begin{array}{l}95 \% \text { Confidence } \\
\text { Interval of the } \\
\text { Difference }\end{array}$} \\
\hline $\begin{array}{l}\text { Equal } \\
\text { varian } \\
\text { ces } \\
\text { assum } \\
\text { ed }\end{array}$ & $\begin{array}{ll}.75 & .45\end{array}$ & .14 & 58 & .888 & .316 & 2.24 & -4.17 & 4.80 \\
\hline $\begin{array}{l}\text { Equal } \\
\text { varian } \\
\text { ces not } \\
\text { assum } \\
\text { ed }\end{array}$ & & .14 & 57.3 & .888 & .316 & 2.24 & -4.17 & 4.80 \\
\hline
\end{tabular}

As also displayed in Graph 1, the mean of pretest of writing by groups (experimental vs. control) was 78.53 and 78.85 respectively. Obviously, the graphs were not statistically different prior to the treatment.

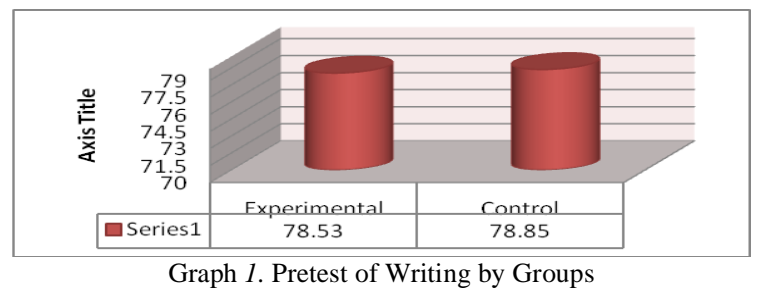

\section{Testing the Major Hypothesis}

The major hypothesis assuming “dictogloss does not have any significant effect on developing EFL learners' general writing ability" was tested on the basis of ANCOVA.

As displayed in Table 6, the mean scores for experimental and control groups on posttest of writing are 86.46 and 84.31 , respectively. The experimental group after receiving dictogloss treatment outperformed the control group on the posttest of writing.

TABLE 6.

DESCRIPTIVE STATISTICS POSTTEST OF WRITING BY GROUPS

\begin{tabular}{lllll}
\hline Group & $\mathrm{N}$ & Mean & Std. Deviation & Std. Error Mean \\
\hline Experimental & 30 & 86.466 & 9.21761 & 1.68290 \\
Control & 30 & 84.316 & 8.66571 & 1.58214 \\
\hline
\end{tabular}

An analysis of covariance (ANCOVA) was run to compare the experimental and control groups' mean scores on posttest of writing in order to probe that the effect of dictogloss on the improvement of the writing ability of the Iranian EFL learners while controlling for possible effects of their entry knowledge as measured through the pretest. Besides the four assumptions discussed above, ANCOVA is based on two more assumptions, i.e. homogeneity of regression slope and linear relationship between the covariate and the dependent variable. As displayed in Scatter Plot 2, the assumption of homogeneity of regression slope is met, in that both experimental (dotted line) and control groups (solid line) show the same regression slopes. 


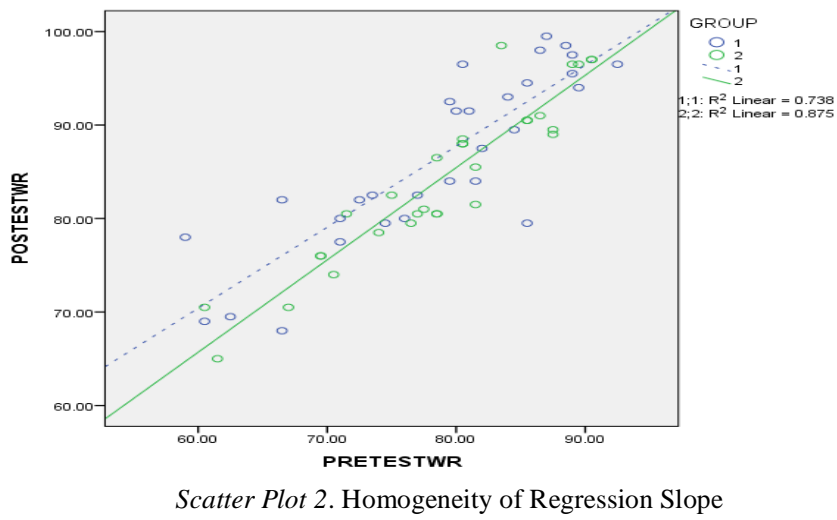

The second assumption, i.e. linear relationship between the dependent variable and covariate was examined within the main table of ANCOVA results. The F-observed value for the covariate is significant $(\mathrm{F}(1,57)=226.61, \mathrm{P}=.000$ $<.05)$. Since F-ratio is (226.61) larger than 1, it can be concluded that there is a linear relationship between the dependent variable and covariate. Thus the second assumption is also met (Table 7).

TABLE 7.

ANCOVA POSTTEST WRITING BY GROUPS WITH PRETEST

\begin{tabular}{ll|llll}
\hline Source & Type III Sum of Squares & df & Mean square & F & Sig \\
\hline PRETESTWR & 3708.834 & 1 & 3708.83 & 226.615 & .000 \\
GROUP & 89.389 & 1 & 89.389 & 5.46 & .023 \\
Error & 932.874 & 57 & 16.366 & & \\
Total & 442215.250 & 60 & & & \\
\hline
\end{tabular}

Furthermore, based on Table 7 the F-observed value for the effect of the independent variable (dictogloss vs. control) is significant $(\mathrm{F}(1,57)=5.46, \mathrm{P}=.023<.05)$, because F-ratio is $(5.46)$ larger than 1 , therefore, it is claimed that the treatment has had a significant effect.

\section{Testing the Minor Hypotheses}

Content Factor

The first minor hypothesis entitled "dictogloss does not have any significant effect on developing EFL learners' ability to develop appropriate contents when writing in English" was targeted by running t-test.

Since the assumption of homogeneity of regression slope was not met, an independent gained t-test was run instead of ANCOVA to investigate the effect dictogloss on the improvement of the Iranian EFL learners' ability in developing appropriate content when writing in English.

As displayed in Table 8, the mean gained scores for the experimental and control groups are 1.41 and 1.63

TABLE 8.

DESCRIPTIVE STATISTICS CONTENT GAINED SCORE BY GROUPS

\begin{tabular}{lllll}
\hline Group & $\mathrm{N}$ & Mean & Std. Deviation & Std. Error Mean \\
\hline Experimental & 30 & 1.416 & 4.27 & .77980 \\
Control & 30 & 1.6333 & 1.71 & 31251 \\
\hline
\end{tabular}

As presented in Table 9, the results of the independent $\mathrm{t}$-test $(\mathrm{t}(58)=.258, \mathrm{P}=.798>.05)$ indicate that there is not any significant difference between experimental and control groups' mean scores on the gained score of the content. Since t-observed (i.e. .25) is less than the respective t-critical (i.e. 2.02) at $58 \mathrm{df}$ and 0.5 level of significance, data failed to reject the first minor null-hypothesis as dictogloss does not significantly effect developing EFL learners' ability to develop appropriate content while writing in English.

TABLE 9.

INDEPENDENT GAINED T-TEST CONTENT GAINED SCORE BY GROUPS

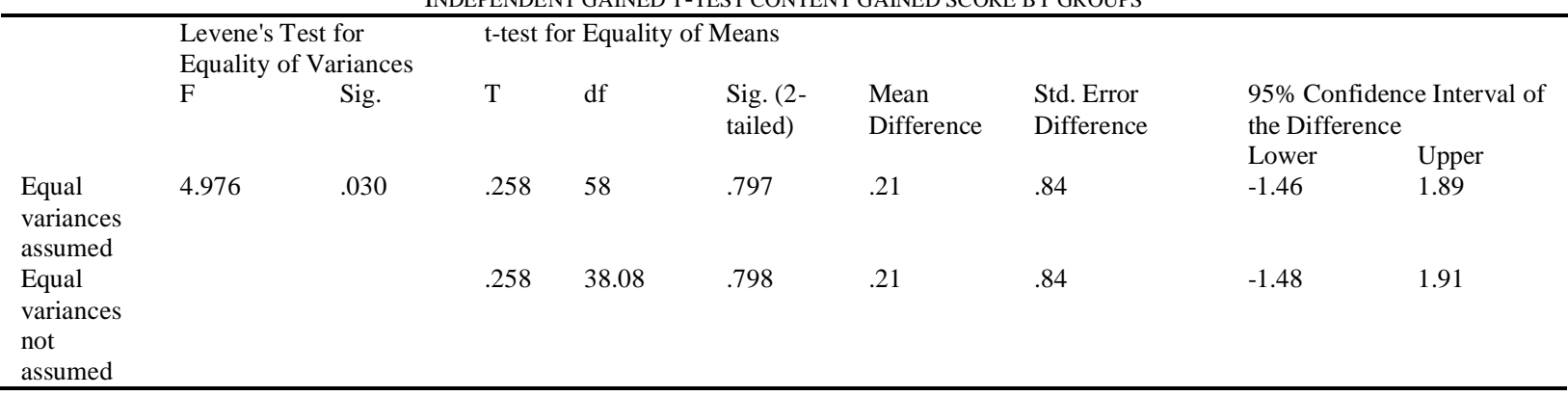




\section{Organization Factor}

The second minor hypothesis assuming "dictogloss does not have any significant effect on developing EFL learners' ability to develop appropriate organization when writing in English" was tested on the basis of ANCOVA.

As displayed in Table 10, the mean scores for experimental and control groups on posttest of writing organization are 18.61 and 16.66, respectively.

TABLE 10

DESCRIPTIVE STATISTICS POSTTEST OF WRITING ORGANIZATION BY GROUPS

\begin{tabular}{lllll}
\hline Group & $\mathrm{N}$ & Mean & Std. Deviation & Std. Error of mean \\
\hline Experimental & 30 & 18.6167 & 1.7552 & .32046 \\
Control & 30 & 16.6667 & 2.2488 & .41059 \\
\hline
\end{tabular}

An analysis of covariance (ANCOVA) was run to compare the experimental and control groups' mean scores on posttest of writing organization in order to probe that the effect of dictogloss on the improvement of the writing organization of the Iranian EFL learners while controlling for possible effects of their entry knowledge as measured through pretest. As displayed in Scatter Plot 3, the assumption of homogeneity of regression slope is met. Both experimental (above) and control (below) show the same regression slopes.

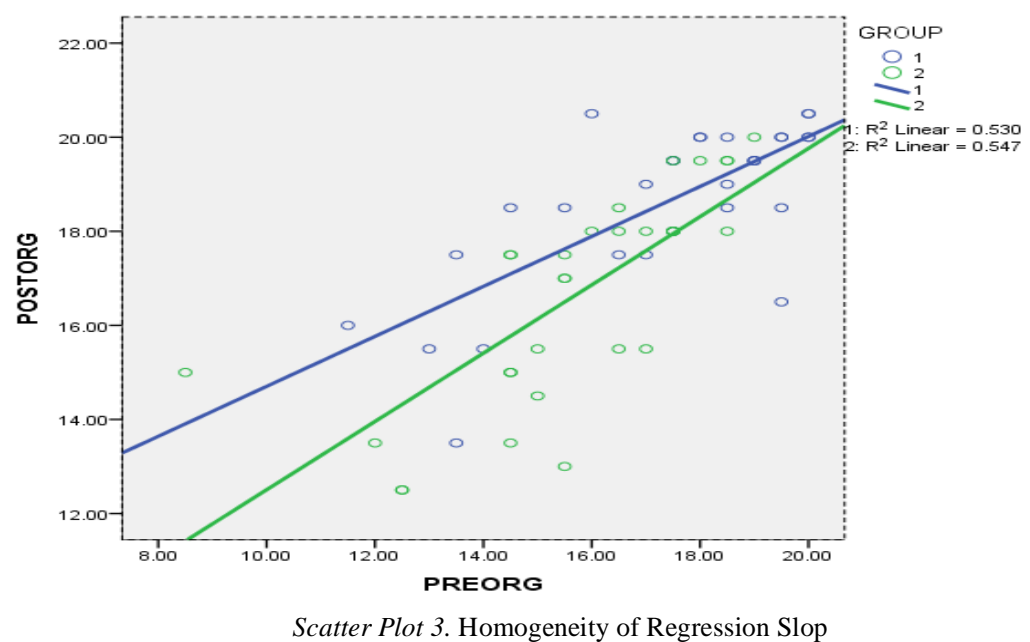

The second assumption, i.e. linear relationship between the dependent variable and covariate is examined within the main table of ANCOVA results. The F-observed value for the covariate is significant $(\mathrm{F}(1,57)=63.77, \mathrm{P}=.000<.05)$. Since F-ratio is (63.77) larger than 1, it can be concluded that there is a linear relationship between the dependent variable and covariate. Thus the second assumption is also met (Table 11).

According Table11, the F-observed value for the effect of the independent variable (dictogloss vs. control) is significant $(\mathrm{F}(1,57)=5.91, \mathrm{P}=.018<.05)$. Since F-ratio is (5.91) larger than 4.01, the second minor null-hypothesis as dictogloss does not have any significant effect on developing EFL learners' ability to develop appropriate organization when writing in English is rejected.

TABLE 11.

ANCOVA POSTTEST WRITING ORGANIZATION BY GROUPS WITH PRETEST

\begin{tabular}{|c|c|c|c|c|c|}
\hline Source & Type III Sum of Squares & $\mathrm{df}$ & Mean Square & $\mathrm{F}$ & Sig. \\
\hline PRETEST ORG & 124.620 & 1 & 124.62 & 63.771 & .000 \\
\hline GROUP & 11.564 & 1 & 11.564 & 5.917 & .018 \\
\hline Error & 111.388 & 57 & 1.954 & & \\
\hline Total & 18966.750 & 60 & & & \\
\hline
\end{tabular}

Graph 4 shows the mean of posttest of writing organization by groups (experimental vs. control) are 18.62 and 16.67, respectively. 


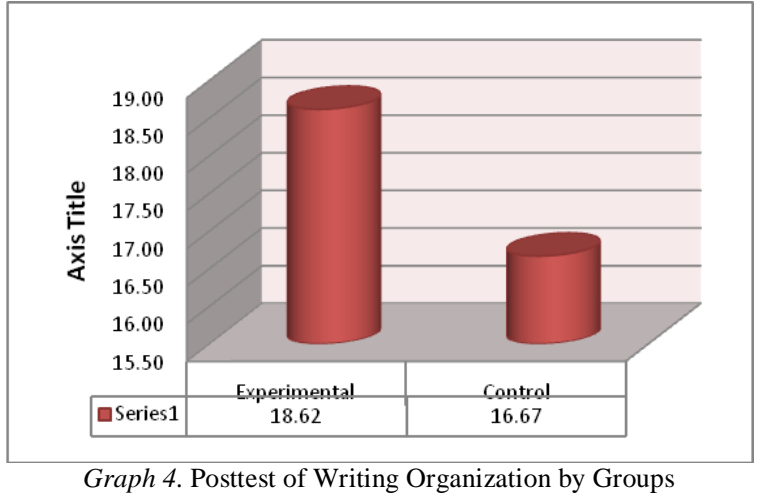

\section{Vocabulary Factor}

The third minor hypothesis entitled "dictogloss does not have any significant effect on developing EFL learners' ability to use appropriate vocabulary when writing in English" was tested by running t-test. As displayed in Table 12 the mean gained scores for the experimental and control groups are 1.60 and 1.33 .

TABLE 12.

DESCRIPTIVE STATISTICS VOCABULARY GAINED SCORE BY GROUPS

\begin{tabular}{lllll}
\hline Group & $\mathrm{N}$ & Mean & Std. Deviation & Std. Error Mean \\
Experimental & 30 & 1.600 & 2.04434 & .37324 \\
Control & 30 & 1.333 & 1.79719 & .32812 \\
\hline
\end{tabular}

Based on Table 13, the results of the independent $\mathrm{t}$-test $(\mathrm{t}(58)=.537, \mathrm{P}=.594>.05)$ indicate that there is not any significant difference between experimental and control groups' mean scores. Since t-observed (i.e. 0.53) is less than the respective t-critical (i.e. 2.02) at $58 \mathrm{df}$ and 0.5 level of significance, the data failed to reject the third minor nullhypothesis as dictogloss does not have any significant effect on developing EFL learners' ability to use appropriate vocabulary when writing in English.

TABLE 13.

INDEPENDENT GAINED T-TEST VOCABULARY GAINED SCORE BY GROUPS

\begin{tabular}{|c|c|c|c|c|c|c|c|c|c|c|}
\hline & \multicolumn{3}{|c|}{$\begin{array}{l}\text { Levene's Test for } \\
\text { Equality of Variances }\end{array}$} & \multicolumn{3}{|c|}{ t-test for Equality of Means } & \multirow{3}{*}{$\begin{array}{l}\text { Mean } \\
\text { Difference }\end{array}$} & \multirow{3}{*}{$\begin{array}{l}\text { Std. Error } \\
\text { Difference }\end{array}$} & & \\
\hline & $\mathrm{F}$ & Sig. & . & $\mathrm{T}$ & df & $\begin{array}{l}\text { Sig. }(2- \\
\text { tailed })\end{array}$ & & & $\begin{array}{l}95 \% \text { Confidence Interval } \\
\text { of the Difference }\end{array}$ & \\
\hline & & & & & & & & & Lower & Upper \\
\hline $\begin{array}{l}\text { Equal } \\
\text { variances } \\
\text { assumed }\end{array}$ & .003 & .955 & & .53 & 58 & .594 & .26 & .49 & -.72 & 1.26 \\
\hline $\begin{array}{l}\text { Equal } \\
\text { variances not } \\
\text { assumed }\end{array}$ & & & & .53 & 57.06 & .594 & .26 & .49 & -.72 & 1.26 \\
\hline
\end{tabular}

\section{Usage Factor}

The fourth minor hypothesis assuming "dictogloss does not have any significant effect on developing EFL learners' ability to develop appropriate language usage when writing in English" was tested on the basis of ANCOVA.

As displayed in Table 14 the mean scores for experimental and control groups on posttest of writing content are 18.61 and 16.66 respectively.

TABLE14.

DESCRIPTIVE STATISTICS POSTTEST OF WRITING ORGANIZATION BY GROUPS

\begin{tabular}{lllll}
\hline Group & $\mathrm{N}$ & Mean & Std. Deviation & Std. Error Mean \\
\hline Experimental & 30 & 18.6167 & 1.75521 & .32046 \\
Control & 30 & 16.6667 & 2.24888 & .41059 \\
\hline
\end{tabular}

An analysis of covariance (ANCOVA) was run to compare the experimental and control groups' mean scores on posttest of language usage in order to probe that the effect of dictogloss on the improvement of the language use of the Iranian EFL learners while controlling for possible effects of their entry knowledge as measured through pretest. As displayed in Scatter Plot 5, the assumption of homogeneity of regression slope is met. Both experimental (above) and control (below) groups show the same regression slopes. 


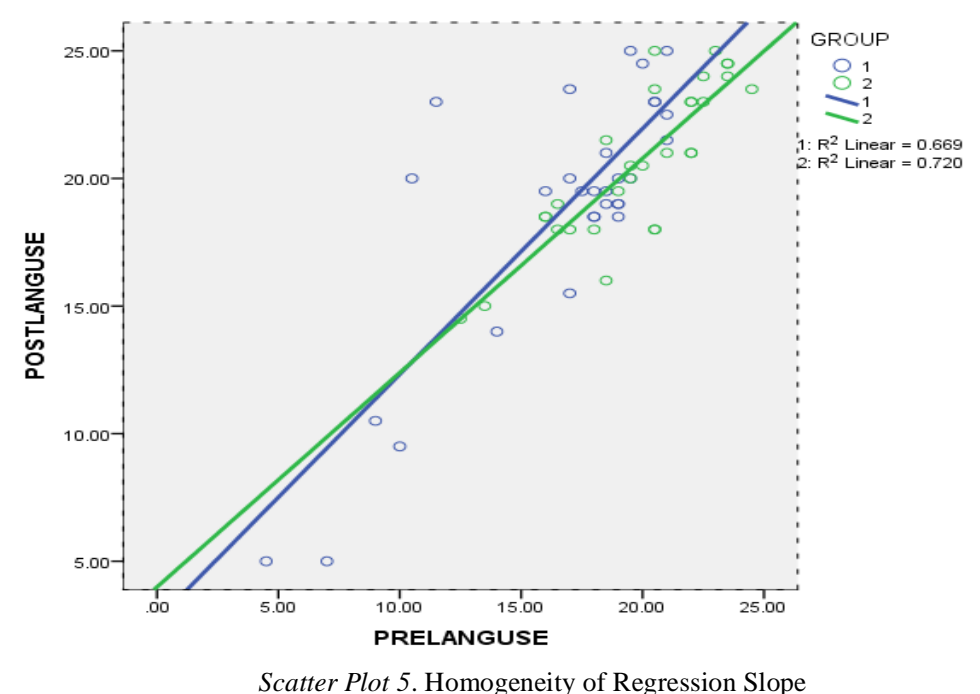

The second assumption, i.e. linear relationship between the dependent variable and covariate is examined within the main table of ANCOVA results. As presented in Table 16 the F-observed value for the covariate is significant $(\mathrm{F}(1,57)$ $=120.54, \mathrm{P}=.000<.05)$. Since F-ratio $(120.54)$ is larger than 1 , it can be concluded that there is a linear relationship between the dependent variable and covariate. Thus the second assumption is also met (Table 15).

TABLE 15.

ANCOVA POSTTEST LANGUAGE USAGE BY GROUPS WITH PRETEST

\begin{tabular}{llllll}
\multicolumn{5}{c}{ ANCOVA POSTTEST LANGUAGE USAGE BY } & GROUPS WITH PRETEST \\
\hline Source & Type III Sum of Squares & df & Mean Square & F & Sig. \\
PRETEST ORG & 714.554 & 1 & 714.554 & 120.54 & .000 \\
GROUP & 13.295 & 1 & 13.295 & 2.24 & .140 \\
Error & 337.888 & 57 & 5.928 & & \\
Total & 24373.250 & 60 & & & \\
\hline
\end{tabular}

The F-observed value for the effect of the independent variable (dictogloss vs. control) is not significant $(\mathrm{F}(1,57)=$ $2.24, \mathrm{P}=.140>.05)$. Since F-ratio $(2.24)$ is less than 4.01 , it can be concluded that there is not any significant difference between the mean scores of the experimental and control groups on the posttest of language usage after controlling for possible effect of their entry knowledge as measured through the pretest. Thus, the data failed to reject the fourth minor null-hypothesis as dictogloss does not have any significant effect on developing EFL learners' ability to employ appropriate language usage when writing in English.

Mechanics Factor

The fifth minor hypothesis entitled “dictogloss does not have any significant effect on developing EFL learners' ability to use appropriate mechanics when writing in English" was tested by running t-test.

As displayed in Table 16 the mean gained scores for the experimental and control groups are 1.16 and .53, respectively

TABLE 16.

DESCRIPTIVE STATISTICS MECHANICS GAINED SCORE BY GROUPS

\begin{tabular}{lcccc}
\multicolumn{5}{c}{ DESCRIPTIVE STATISTICS MECHANICS GAINED SCORE BY GROUPS } \\
\hline & $\mathrm{N}$ & Mean & Std. Deviation & Std. Error Mean \\
\hline Group & & & & \\
Experimental & 30 & 1.1667 & 1.28206 & .23407 \\
Control & 30 & .5333 & .71840 & .13116 \\
\hline
\end{tabular}

Based on Table 17 the results of the independent $\mathrm{t}$-test $(\mathrm{t}(45)=2.36, \mathrm{P}=.023<.05)$ indicate that there is a significant difference between experimental and control groups' mean scores on the gained score of the mechanics because $t-$ observed (i.e. 2.36) is more than the respective t-critical (i.e. 2.02) at $58 \mathrm{df}$ and 0.5 level of significance. Thus the fifth minor null-hypothesis as dictogloss does not have any significant effect on developing EFL learners' ability to use appropriate mechanics when writing in English is rejected. 
TABLE 17.

INDEPENDENT GAINED T-TEST MECHANICS GAINED SCORE BY GROUPS

\begin{tabular}{|c|c|c|c|c|c|c|c|c|c|}
\hline & \multirow{3}{*}{\multicolumn{2}{|c|}{$\begin{array}{l}\text { Levene's Test for } \\
\text { Equality of } \\
\text { Variances } \\
\text { F Sig. }\end{array}$}} & \multicolumn{7}{|c|}{ t-test for Equality of Means } \\
\hline & & & \multirow[t]{2}{*}{$\mathrm{T}$} & \multirow[t]{2}{*}{$\mathrm{df}$} & \multirow[t]{2}{*}{$\begin{array}{l}\text { Sig. (2- } \\
\text { tailed) }\end{array}$} & \multirow[t]{2}{*}{$\begin{array}{l}\text { Mean } \\
\text { Difference }\end{array}$} & \multirow[t]{2}{*}{$\begin{array}{l}\text { Std. Error } \\
\text { Difference }\end{array}$} & \multicolumn{2}{|c|}{$\begin{array}{l}95 \% \text { Confidence Interval } \\
\text { of the Difference }\end{array}$} \\
\hline & & & & & & & & Lower & Upper \\
\hline $\begin{array}{l}\text { Equal variances } \\
\text { assumed }\end{array}$ & 8.824 & .004 & 2.36 & 58 & .022 & .63 & .26 & .09 & 1.17 \\
\hline $\begin{array}{l}\text { Equal variances } \\
\text { not assumed }\end{array}$ & & & 2.36 & 45.5 & .023 & .63 & .26 & .09 & 1.17 \\
\hline
\end{tabular}

\section{DISCUSSION AND CONCLUSION}

The primary goal of this study was to explore the effect of dictogloss on writing performance. In order to address the first research question, the data were collected to analyze through ANCOVA. The answer was statistically positive. The results suggest that there is a significant difference between the mean scores of experimental and control group. This finding is consistent with Jacobs and Small (2003) who reported the positive effect of dictogloss on writing performance.

Since the writing papers were scored analytically based on Heaton's five scales of measurement (1998), the researchers decided to compare each scale separately based on the participants' performance both prior and after the treatment.

The first scale was "content". These deals with how much learners write down relevantly regarding to topic. The result revealed no significant difference between experimental and control group's writing. It was found out both groups composed relevant; however, the experimental group could write more. While mostly learners nag about lack of idea in their compositions and also mention that they cannot write about this topic even in their mother tongues let alone English language, dictogloss provided them a great deal of ideas for each topic. So it shows that these ample of ideas during the 8 sessions of dictogloss widened the scope of their knowledge and helped them to write more for the post test. It might also be concluded that learners become more interested toward writing and this interest leads them to write more.

The second scale was "organization ". It concerns about how learners state their opinions and whether it is fluent or not. An analysis of covariance marked the effect of dictogloss on experimental group's writings regarding the organization. As indicated before, during dictogloss sessions learners were faced more ideas and opinions and their general knowledge started strengthening. Consequently, they had more supporting sentences and could link sentences better in their post writing.

As a third scale, Heaton mentions the "range of vocabulary" in writings. The result was statistically negative and contradicted the earlier study by Pishghadam (2011) who reported the effect of dictogloss on learning new vocabularies. Although during the semantic mapping learners were introduced new vocabularies and idioms, it seems that on one hand just facing new vocabularies is not enough for learning them and on the other hand writing through dictogloss is not long enough for learners to learn and practice new vocabularies. Furthermore, during the reconstruction stage learners were more integrated in propositional meaning of the text rather than in vocabulary learning.

The fourth scale was dedicated to "language usage" that is about language constructions. It focuses on whether learners have mastery of sentence construction rules or not. The finding was unexpected since a number of empirical studies (Storch, 1998; Nabei, 1996; Lim \& Jacobs, 2001) investigating the effect of dictogloss on variance aspects of language performance, found the strong support for the efficacy of dictogloss. In fact, the result of this study seems to agree, to a large extent, with minority of studies (Kuiken \&Vedder, 2002; Al-Siba, 2008) which found no significant difference in their participants' language performance especially in grammar. Kuiken and Vedder (2002) concluded that although the quantitative analysis does not show significant gains when learners are given the opportunity to interact, the results of the qualitative analysis seem to be promising. They further mentioned that the qualitative analysis, however, has revealed that interaction often stimulated noticing but not acquisition. Therefore there might be other factors like genre, subject, style and difficulty of the text that complicate the relationship between interaction, noticing and acquisition.

"Mechanics" was the fifth scale of the researcher's scoring rubric. It is concerned with spelling, punctuation, capitalization, and paragraphing. The result demonstrated that there was a significant difference between experimental and control groups' mean scores on the mechanics. Therefore, this finding confirms the previous study by Linden (1994) who considered dictogloss as a powerful technique for learning spelling and punctuations.

In conclusion, dictogloss has a positive effect on EFl learners' general writing. It can enhance their organization and mechanics but not content, language usage and vocabulary of EFL learners' writing. 


\section{REFERENCES}

[1] Al-Sibai, D. M. M. (2008). Using Dictogloss Tasks: Attention to Form In a Collaborative Classroom Activity with Female Students at King Saud University. Master,King Saud University, Proquest.

[2] Ellis, R. (2001). Form-Focused Instruction and Second Language. Oxford: Blackwell Publishing. 1-46.

[3] Jacobs, G. \& Small, J. (2003). Combining dictogloss and cooperative learning to promote language learning. The Reading Matrix 3.1,1-15.

[4] Lim, L. \& Jacobs, G. (2001a). An analysis of students' pairic interaction on a dictogloss task. Retrieved October 2, 2005, from ERIC database.

[5] Kuiken, F., \& Vedder, I. (2002). The effect of interaction in acquiring the grammar of a second language. International Journal of Educational Research 37.3\&4, 343-358, doi: 10.1016/s0883-0355(03)00009-0.

[6] Linden, M. (1994). Improving Grammar and Other Writing Skills with Text Reconstruction (TR). A paper presented at the Fifth Annual Conference of the NCTE Assembly for the Teaching of English Grammar. Retrieved March 9, 2006, from www.ateg.org/ conferences/c5/linden.htm.

[7] Mayo, M. (2002). The effectiveness of two form-focused tasks in advanced EFL pedagogy. International Journal of Applied Linguistics 12.2, 156-175.

[8] Nabei, T. (1996). Dictogloss: Is it an effective language learning task? Working Papers in Educational Linguistics 12. 1, 59-74.

[9] Nassaji, H. F., S. ((2004). Current developments in research on the teaching of grammar. Annual Review of Applied Linguistics, 24,1-19.

[10] Pica, T. (1997). Second language teaching and research relationships: a North American view. Language Teaching Research $1.1,48-7$.

[11] Pica, T. (2000). Tradition and Transition in English Language Teaching Methodology. System 28, 1-18

[12] Pishghadam, R., \& Javadan Mehr, F. (2011).Learner creativity and performance in written narrative task. World Journal of Education 1.2, 115-135.

[13] Qin, J. (2002). The effect of processing instruction and dictogloss task on acquisition of the English passive voice. Language Teaching and Research 12.1, 61-82.

[14] Read, J. 2009.Teaching grammar through grammar dictation. Retrieved October 19, 2012, From http://your.usc.edu.au/wacana/4/read.htm.

[15] Shak. (2006). Children using dictogloss to focus on form. Reflections on English Language Teaching 5.2, 47-62.

[16] Storch, N. (2001). Comparing esl learners' attention to grammar on three different classroom tasks. RELC Journal 32.2, 104124.

[17] Swain, M., \& Lapkin, S. (1998). Interaction and second language learning: two adolescent French immersion students working together. The Modern Language Journal 82.3, 320-337.

[18] Thornbury, S. (1997). Reformulation and reconstruction: tasks that promote 'noticing'. ELT Journal Volume 51.4.326-335.

[19] Vasiljevic, Z. (2010). Dictogloss as an interactive method of teaching listening comprehension to 12 learner. English Language Teaching 3.1, 41-52.

Gholam-Reza Abbasian, assistant professor of TEFL at Imam Ali and Islamic Azad (South Tehran Branch) universities. He has presented at a good number of both national and international conferences. He is also the author of five books and has translated at least ten others. Furthermore, he has published several scholarly articles in national and international academic journals.

Mahsa Mohammadi, a PhD candidate at University of Tehran (Alborz Pardis) and holds an M.A. in TEFL from Islamic Azad University, South Brach, Iran. She is an adjunct professor at Islamic Azad University of Damavand and is also involved in teaching at various institutes and educational centers. She is also more interested in doing research in the areas of syllabus design and adult second language learning. 